\title{
Acknowledgements
}

This thesis is the product of countless beautiful, inspiring, and challenging discussions and encounters I had the honour of experiencing during these recent years. I would like to thank my supervisor, Encarnación Gutiérrez Rodríguez, for her trust in me, her support, and her critical guidance over all these years. I am grateful to my second supervisor, Olaf Kaltmeier, for his kind and encouraging feedback, as well as for his exemplary research on the Mapuche resistance. I would like to thank all of my wonderful colleagues at Justus-Liebig University, particularly the General Sociology team, and at the Institute for Sociology, as well as my students, for giving me the strength, inspiration, and motivation to go on. For walking together towards a $\mathrm{PhD}$ (or for pointing out the path), I would like to thank my colleagues Andrea Sempértegui, Andrea Silva-Tapia, María Cárdenas, Andreea Racles, Pinar Tuzcu, Lisa Doppler, Andrea Newerla, Jeanette Ehrmann, Sheila Ragunathan, Gisèle Oldorff, Hannes Kaufmann, Eugenia van Engelenhoven, Çiçek Tanli, and Ceren Türkmen. Also, I extend my gratitude to the staff, PhD students, and postdoctoral fellows at the GCSC for giving me an institutional and academic home for three years.

Despite its precariousness, academia gave me the opportunity to travel and to make friends and new colleagues in different places. I am grateful for the encounters with my dear colleagues and friends at the University of the West Indies in Trinidad and Tobago, especially Rhoda Reddock, Gabrielle Hosein, Sue-Ann Barratt, Shelene Gomes, Dylan Kerrigan, Talia Esnard, and Dean Arlen; Shirley Tate of the University of Alberta; and Claudia Zapata of the University of Chile. I also extend my gratitude to my colleagues and friends in Germany and beyond for their constant companionship. Whilst I cannot mention all of them, a special thanks goes to Christine Löw, Laura Florez, Tobias Boos, Jan Hutta, Yuderkys Espinosa Miñoso, Gladys Tzul, William Callison, Daniel Bendix, Julia Schöneberg, Lata Narayanaswamy, and Stefan Khittel. 
This thesis owes a lot to discussions and encounters with decolonial and antiracist activists and initiatives in Germany, such as frankfurt postkolonial, giessen postkolonial, the Initiative Schwarzer Menschen in Deutschland, and glokal e.V. They continually made me understand how important this work in our own white backyard actually is.

I would not have been able to pursue this project without the kind and open disposition to discuss Mapuche solidarity and advocacy by the members of the regional group of the Gesellschaft für bedrohte Völker in Cologne, particularly Alex Mora and Alina Rodenkirchen, as well as its team in the Göttingen headquarters, foremost Yvonne Bangert. I am deeply grateful for the encounters with so many Mapuche and non-Mapuche activists in Europe, particularly Llanquiray Painemal; Andrea Cotrena; Rafael, María, and Rosario Railaf; Alex Hespe; Ronja; and Adriane Lavieri-you all contributed to this process, not only with your knowledge, but with your food, laughter, kindness, and care. I would like to thank Britt Weyde from the Informationsstelle Lateinamerika in Bonn and the Informationsbüro Nicaragua team for their kind and generous support of my archive work. I extend my gratitude to the Unrepresented Peoples Organisation (UNPO) and Adveniat for their insights and for sharing their contacts. And, of course, I would like to thank all those engaged activists in Latin American solidarity all over Europe whom I encountered over the last few years. A special thanks goes out to Gala Montero, Susanne Kratzer, and May Ramírez, who aided this research with their logistical support, and to Sofia Kouropatov from Pelican Editing for her excellent and thorough proof reading. I would also like to thank Jakob Horstmann and Julia Wieczorek from transcript Verlag for their continuous support and encouraging feedback throughout the publication process.

My research in Chile would not have been possible without the support of my friends, compañeras, and compañeros, foremost my Chilean family, Cárcamo Calderón and Schulbaum, Anna Piquard and Rayen Kvyeh, Vicente Painel and Jorge Huichalaf, Iris Mora and family, Gastón Manquecoy, Rubén Collío and family, Godofredo Cotrena, Ingrid Conejeros, Jaime and Griselda Huenchullán and family, Eric Catrileo and family, Fernando Díaz, Juan Fuenzálida, Luis Rodríguez Tupper and his team, Victor Carilaf, José Luis Calfucura, Pablo Calfuqueo and the whole community of Llaguepulli, Manuel and Ceferino Painiqueo and their families, Isabel Cañet, and Ingrid Wehr and her team.

In addition, I want to thank my friends and family for their support and motivation through all those years: Pete, Stephie, Maritza, Niklas, Amelie, Renate, and Marisa. Mil gracias to my Latin American friends, from the Andes 
to the Alps, in Frankfurt and Offenbach, my people in Vienna, and to Imke, Sebastian, and family for their care and support in times of crisis. I would like to thank Seb, Tobi, David, and Basti for your brotherly love and for keeping me in balance. I deeply miss my grandparents Werner and Gertrud, as well as my dear friend Christin, who helped to plant the seeds but will not be able to see the fruits of this work. Thank you, Johanna and Theresa, for shining your lights into our lives and for inspiring us to build a better future. Finally, this work is a reflection about solidarity beyond differences and is therefore inspired by my mother, sister, and father. 


\section{Tain kimun}

ta tain keyagun mvleai kvme mogen ti fachi nag mapu meu.

El conocimiento

y la solidaridad de los pueblos es la llave de la paz en el mundo.

The knowledge

and the solidarity of the people are the key to peace in the world.

Rayen Kvyeh 